\title{
Chapter 1 \\ Quality and Standards for Haematopoietic Stem Cells Transplantation Programs
}

\author{
Eoin McGrath and Dunia Jawdat
}

\section{Quality}

The word "quality" emerged in the fourteenth century from the Latin "qualis" and the French "qualitie" [1]. Quality in healthcare as we know it today can trace its origins back to the early twentieth century when a number of measures were taken to address great variations in medical education and care [2]. The WHO defines quality of health care as "the extent to which health care services provided to individuals and patient populations improve desired health outcomes". ${ }^{1}$

Quality itself is not a static concept - in its dynamic form, it becomes continuous improvement [3]. Furthermore, quality assurance (QA), concerned with compliance, should not be considered to be the same as quality improvement (QI), which is defined as the framework we use to systematically improve the ways care is delivered to patients [4]. Quality improvement has been further defined as "the combined and unceasing efforts of everyone - healthcare professionals, patients and their families, researchers, payers, planners and educators - to make the changes

${ }^{1}$ www.who.int/maternal_child_adolescent/topics/quality-of-care/definition/en/consulted 11/06/2020.

E. McGrath $(\bowtie)$

JACIE Accreditation Office, EBMT, Barcelona, Spain

e-mail: eoin.mcgrath@ebmt.org

D. Jawdat

Cord Blood Bank, Saudi Stem Cell Donor Registry, King Abdullah International Medical

Research Center, Riyadh, Saudi Arabia

Department of Science, College of Science and Health Professions, King Saud bin Abdulaziz

University for Health Sciences, Ministry of National Guard Health Affairs,

Riyadh, Saudi Arabia

e-mail: jawdatd@ngha.med.sa 
that will lead to better patient outcomes (health), better system performance (care) and better professional development" [5].

In 1966, Avedis Donabedian (1919-2000), one of the great pioneers of quality in healthcare, introduced the concepts of structure, process, and outcome as the basis to evaluate the quality of health care. "Structure" includes the settings, qualifications of providers and administrative systems through which care takes place; "process" as the components of care delivered and "outcome" as recovery, restoration of function and survival [6]. These concepts will probably be familiar to readers today even if they are not aware of their origins. In HSCT, structure would include the physical facilities where care is delivered, the experience and qualification of the medical and laboratory teams, the overall support structure and regulatory and reimbursement frameworks. Process would be how the patient and the healthcare system interact, e.g. referral from primary healthcare provider to tertiary care and necessary testing. Outcome includes the effect of care on diseases and their prevention, such as the mortality rate, the error rate and the quality of life [7].

The concept of quality management (QM) has been known since the 1950s and applied by different sectors for many years. However, in the field of cellular therapy, it is relatively new in comparison to quality assurance and quality control. The implementation of a QM programme with its components including quality control, quality assurance, quality assessment and quality improvement advances the quality of service provided for patients and helps programs and stem cell banks to address external threats and internal weaknesses which could negatively impact services and products.

In HSCT, different stakeholders have been identified as holding an interest in ensuring that patients receive quality care: patients, referring physicians, payers, other community healthcare providers, and professional and patient organizations [8].

\section{Standards}

A standard has been defined as "a desired and achievable level of performance against which actual performance is measured" [9]. Standard-setting organisations also consider themselves as facilitators of the above-mentioned evolution from compliance towards improvement [10].

In 1998, the European Society for Blood and Marrow Transplantation (EBMT) and the International Society for Cellular Therapy (ISCT) established the Joint Accreditation Committee - ISCT \& EBMT (JACIE) - to develop international standards and offer an inspection-based accreditation process in the field of HSCT. JACIE is a committee of the EBMT, and its members are appointed by and are accountable to the EBMT Board and ISCT is represented through two members of the Committee. JACIE collaborates with the US-based Foundation for the Accreditation of Cellular Therapy (FACT), a non-profit corporation co-founded by ISCT and the American 
Society of Transplantation and Cellular Therapy (ASTCT), which pioneered the standards and accreditation model starting in the mid-1990s in the USA. JACIE and FACT develop and maintain global standards for the provision of quality medical and laboratory practice in cellular therapy. The FACT-JACIE international standards stand out as an example of a profession-driven initiative to improve quality in transplantation which have subsequently been incorporated by third parties to support healthcare reimbursement (health insurers, social security) and authorization of treatment (regulatory authorities) processes. ${ }^{2}$

In 1974, the first bone marrow registry was founded in the UK, and since then many registries have been established around the world. Hence, for more than four decades, bone marrow registries have been crucial in facilitating the search for haematopoietic stem cells from adult donors or cord blood units for any patient around the world.

In 1988, three pioneers in the field of blood stem cell transplantation, John Goldman, E. Donnell Thomas and Jon J. van Rood, initiated the founding of the Cooperative Marrow Donor Programme, an international collaboration that was essential at that time and led to the official founding of the World Marrow Donor Association (WMDA) in 1994 in Leiden in the Netherlands to give all patients equal access to high-quality stem cells for clinical transplantation by providing international standards and guidelines relating to best practices in every aspect of the registry's operation promoting quality and donor safety. The WMDA established an accreditation programme for unrelated donor registries as an assurance to all organizations involved in HSCT.

Together with FACT accreditation of stand-alone cord blood banks, WMDA accreditation reassures transplant physicians in terms of the quality of product and services provided.

In 2007, EBMT, the Center for International Blood \& Marrow Transplant Research (CIBMTR) and the Asian Pacific Blood and Marrow Transplantation Group (APBMT) together with WMDA among others founded the Worldwide Network for Blood and Marrow Transplantation (WBMT), a non-profit scientific organization aiming to promote excellence in stem cell transplantation, donation and cellular therapy.

Standards in cell therapy are offered through what are typically voluntary schemes such as AABB $,{ }^{3} \mathrm{JACIE},{ }^{4} \mathrm{FACT},{ }^{5} \mathrm{NetCord}^{6}$ and Fundación $\mathrm{CAT}^{7}$ among others and serve to promote patient care and excellence in clinical and laboratory practice by standardizing procedures for the collection, analysis, banking

\footnotetext{
${ }^{2}$ https://www.ebmt.org/regulations-guidelines consulted 22/07/2020.

${ }^{3}$ www.aabb.org/sa/standards/ consulted 11/06/2020.

${ }^{4}$ www.ebmt.org/jacie consulted 11/06/2020.

${ }^{5}$ www.factwebsite.org/ consulted 11/06/2020.

${ }^{6}$ wmda.info/professionals/quality-and-accreditation/netcord-fact-standards/ consulted 11/06/2020.

${ }^{7}$ www.catransfusion.es/.
} 
and administration of cells for transplantation [11]. As an example, the JACIE and FACT accreditation systems are based on the regular update of standards covering the entire transplantation process, from the selection of the donor/ patient to the follow-up, including collection, characterization, processing and storage of the graft. Considering the different competences included in the process, the standards are articulated in 4 parts: Clinical Programme, Bone Marrow Collection, Apheresis Collection and Processing Facility. A QM section is embedded in each part, aimed to provide a tool for both the applicants to develop a comprehensive quality system and the inspectors to check the compliance of the transplant programme to the standards. Processing labs can apply independently; however, the target of the accreditation is the programme, intended as the process in its entirety, thus requiring a full integration of units, laboratories, services and professionals. Each section focuses on the competence of personnel, listing the topics for which the evidence of specific training is required and also including the minimum requirements of experience for positions of responsibility. Maintenance of competencies is also required for all professionals.

The standards are revised on a 3-yearly basis by a commission formed by experts appointed by FACT and JACIE, including specialists in HSCT administration, cell processing and storage, blood apheresis, transplant registries and QM. The standards are based on published evidence and, when this is not available, on expert consensus. A legal review and comparison with current regulations is carried out for each version. When the developmental phase is finalized, the standards are published for public review and comment before being approved by FACT and JACIE. The standards incorporate sound principles of quality medical and laboratory practice in cellular therapy, but they do not cover the legal requirements which fall to the relevant competent authorities.

The standards cover the use of different sources of hematopoietic stem cells and nucleated cells from any hematopoietic tissue source administered in the context of the transplant process, such as donor lymphocyte infusion (DLI). The inclusion of the term "hematopoietic" in the title is to define the scope of these standards due to an increasing number of accredited facilities that also support non-hematopoietic cellular therapies. Since the release of edition 6.1 in 2018, the standards have included new items specifically developed for other cellular therapy products, with special reference to immune effector cells (IEC). This reflects the rapidly evolving field of cellular therapy through mainly, but not exclusively, genetically modified cells such as CAR-T cells. The standards do not cover manufacturing of such cells but include the chain of responsibilities where the product is provided by a third party, usually a pharmaceutical manufacturer, and ensure the competence of the personnel in the management of adverse events related to the infusion and subsequent care. 


\section{Impact}

What if any is the impact on clinical outcomes? - a crucial question given the effort and resources needed to establish and maintain the required standards in each transplant centre and subject to much investigation across healthcare at large [12]. Evidence does exist for HSCT where studies using European HSCT registry data have correlated the different phases of preparation for and achievement of accreditation at centre level with incremental improvements in patient survival and reduction in procedural mortality $[13,14]$. Evidence relating clinical trials participation and FACT accreditation in the United States also indicated a positive impact, although with some mixed findings [15].

Implementing a quality management system and achieving accreditation in the field of cellular therapy by a transplant centre prove the level of commitment to high-quality measures and monitoring cellular therapy practice and downstream patient care. This provides reassurance to patients and their families, healthcare professionals, commercial suppliers, regulatory authorities and insurance payers.

Standards-setting organizations must be alert to the risk of overburdening their users with requirements, falling behind the pace of change or losing the focus on what actually matters to patients: health, safety and optimal experience $[12,16]$. Braithwaite et al propose the need for a new generation of standards that do not just assess compliance but also enable healthcare system transformation and sustainability [16].

\section{Conclusion}

The international take-up of specialized standards in a complex field such as HSCT is due to a number of factors: the early championing by some HSCT leaders emphasizing the need for quality measures to better control a complex process; international professional association support; the early observation at local level of the organisational impact and inclusion among national regulatory requirements. This widespread acceptance then provides a basis to present other aspects, such as standardised performance benchmarking of survival outcomes and minimal centre activity, as further means of quality improvement.

To help guard against overburdening users with unwieldy requirements, ultimately, we must keep in mind why quality - and by extension, standards - is important. Avedis Donabadian said in an interview not long before he died: "Ultimately the secret of quality is love. You have to love your patient, you have to love your profession, you have to love your God. If you have love, you can then work backward to monitor and improve the system" [17]. This simple but powerful statement captures the real purpose of quality. 


\section{Key Points}

- Quality care is firmly established as a goal by healthcare professionals.

- Accreditation based on an internationally agreed standard system led by HSCT professionals is an effective tool to drive quality improvement in transplant programmes.

- Standards are regularly updated to reflect developments and innovation in practice.

- There is evidence that quality of care has been improved in HSCT by applying standards to clinical and laboratory practice.

\section{References}

1. Batalden P. "Quality improvement": noun or verb? Qual Saf Heal Care [Internet]. 2002;11(2):152. Available from: http://qshc.bmj.com/cgi/doi/10.1136/qhc.11.2.152.

2. Merry MD, Crago MG. The past, present and future of health care quality. Urgent need for innovative, external review processes to protect patients. Physician Exec. 2001;27(5):30-5.

3. Atkinson S, Ingham J, Cheshire M, Went S. Defining quality and quality improvement. Clin Med J R Coll Physicians London. 2010;10(6):537-9.

4. Knox L, Brach C. The practice facilitation handbook: training modules for new facilitators and their trainers. 2013;1-144. Available from: http://www.ahrq.gov/sites/default/files/publications/files/practicefacilitationhandbook.pdf.

5. Batalden PB, Davidoff F. What is "quality improvement" and how can it transform healthcare? Qual Saf Health Care [Internet]. 2007;16(1):2-3. Available from: http://www.pubmedcentral. nih.gov/articlerender.fcgi?artid $=2464920 \&$ tool $=$ pmcentre $\&$ rendertype $=$ abstract.

6. Ayanian JZ, Markel H. Donabedian's lasting framework for health care quality. N Engl J Med. 2016;375(3):205-7.

7. Kenyon M, Babic A, editors. The European blood and marrow transplantation textbook for nurses textbook for nurses textbook for nurses textbook for nurses. 1st ed. Cham: Springer International Publishing AG; 2018.

8. Majhail NS. Optimizing quality and efficiency of healthcare delivery in hematopoietic cell transplantation. Curr Hematol Malig Rep [Internet]. 2015;10(3):199-204. Available from: http://www.ncbi.nlm.nih.gov/pubmed/26003329.

9. Greenfield D, Pawsey M, Hinchcliff R, Moldovan M, Braithwaite J. The standard of healthcare accreditation standards: a review of empirical research underpinning their development and impact. BMC Health Serv Res [Internet]. 2012;12(1):329. Available from: http://www. pubmedcentral.nih.gov/articlerender.fcgi? artid=3520756\&tool=pmcentrez\&rendertype $=$ abstract.

10. O'Leary DS, O'Leary MR. From quality assurance to quality improvement: the Joint Commission on Accreditation of Healthcare Organizations and emergency care. Emerg Med Clin North Am. 1992;10:477-92.

11. Vives J, Oliver-Vila I, Pla A. Quality compliance in the shift from cell transplantation to cell therapy in non-pharma environments. Cytotherapy [Internet]. 2015;17(8):1009-14. Available from: http://www.celltherapyjournal.org/article/S1465324915000493/fulltext.

12. Jha AK. Accreditation, quality, and making hospital care better. JAMA [Internet]. 2018;320(23):2410. Available from: http://jama.jamanetwork.com/article.aspx?doi=10.1001/ jama.2018.18810.

13. Gratwohl A, Brand R, Niederwieser D, Baldomero H, Chabannon C, Cornelissen J, et al. Introduction of a quality management system and outcome after hematopoietic stem-cell trans- 
plantation. J Clin Oncol [Internet]. 2011; 29(15):JCO.2010.30.4121-. Available from: http:// jco.ascopubs.org/cgi/content/abstract/JCO.2010.30.4121v1.

14. Gratwohl A, Brand R, McGrath E, van Biezen A, Sureda A, Ljungman P, et al. Use of the quality management system "JACIE" and outcome after hematopoietic stem cell transplantation. Haematologica [Internet]. 2014;99(5):908-15. Available from: http://www.pubmedcentral. nih.gov/articlerender.fcgi?artid $=4008105 \&$ tool $=$ pmcentrez\&rendertype $=$ abstract.

15. Marmor S, Begun JW, Abraham J, Virnig BA. The impact of center accreditation on hematopoietic cell transplantation (HCT). Bone Marrow Transplant [Internet]. 2015;50(1):87-94. https://doi.org/10.1038/bmt.2014.219.

16. Braithwaite J, Vincent C, Nicklin W, Amalberti R. Coping with more people with more illness. Part 2: new generation of standards for enabling healthcare system transformation and sustainability. Int J Qual Heal Care. 2019;31(2):159-63.

17. Mullan F. A founder of quality assessment encounters a troubled system firsthand. Health Aff [Internet]. 2001;20(1):137-41. Available from: https://www.healthaffairs.org/doi/pdf/10.1377/ hlthaff.20.1.137.

Open Access This chapter is licensed under the terms of the Creative Commons Attribution 4.0 International License (http://creativecommons.org/licenses/by/4.0/), which permits use, sharing, adaptation, distribution and reproduction in any medium or format, as long as you give appropriate credit to the original author(s) and the source, provide a link to the Creative Commons license and indicate if changes were made.

The images or other third party material in this chapter are included in the chapter's Creative Commons license, unless indicated otherwise in a credit line to the material. If material is not included in the chapter's Creative Commons license and your intended use is not permitted by statutory regulation or exceeds the permitted use, you will need to obtain permission directly from the copyright holder.

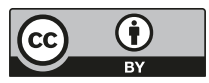

